\title{
DETERMINANTS OF THE FIRM'S CAPITAL STRUCTURE: EVIDENCE FROM DHAKA STOCK EXCHANGE
}

\author{
Muhammad Shahadat Hossain Siddiquee ${ }^{1}$ \\ Abdulla Abu Saker ${ }^{2}$
}

\begin{abstract}
The core objective of the study is to explore empirically the determinants of the capital structure measured in terms of leverage and the existence of linkages in the capital structure of the companies enlisted in the Dhaka Stock Exchange (DSE) using the recent ten years' historical annual data from 2006 to 2015. The theoretical attributes of the capital structure have been examined using the tangibles assets, profitability, size of the company, and growth opportunity as explanatory variables. Findings from the Feasible Generalized Least Square (FGLS) reveal that tangibility, size, and growth opportunity contributes positively to the capital structure whereas profitability impacts the capital structure negatively. These findings might have serious policy implications for achieving desired capital structure for the companies enlisted in the DSE.
\end{abstract}

Keywords: firms, capital structure, Dhaka Stock Exchange, fixed effects, random effects, Feasible Generalized Least Square

\section{Introduction}

A well-functioning capital market helps firms to avail of the required equity and debt (i.e., capital structure) for their different financial needs as well as to contribute to the country's economic growth and employment through ensuring the firms to finance its prospective growth opportunities. A sound capital market ensures the smooth flow of funds from the savers who have it (surplus unit) to the firms who need it (deficit unit). Fundraising or capital structure decision is one of the most important aspects of a firm's growth and sustainability. Moreover, maximizing shareholders' values, allocating risks, and controlling power among

\footnotetext{
1 Muhammad Shahadat Hossain Siddiquee, PhD is Professor, Department of Economics, University of Dhaka, Email: siddiquee.econdu@ gmail.com

2 Abdulla Abu Saker is Deputy Director, Bangladesh Bank, E-mail: abu.sarker@bb.org.bd
}

Social Science Review [The Dhaka University Studies, Part-D], Vol. 37, No. 2, December 2020 
the groups of stakeholders are embedded in the capital structure decisions. All these imply importance to examine how the tangibles assets, the profitability of the firms, the size of the companies, and their growth opportunities determine the capital structure (leverage). Despite such importance, very few studies have focused to identify the primary determinants of the capital structure using the panel data for Bangladesh. This study explores this using the panel data from listed firms in the Dhaka Stock Exchange (henceforth DSE).

In general, firms all over the world face difficulties, and complications in deciding the optimal capital structure, which is a widely debated issue (i.e., the debate over equity vs. debt). Therefore, top executives of the firms have to take this major decision based on a critical analysis of the means of financing the firms. Executives with sound knowledge on managerial capability, the functioning of the market, the financial needs of the companies, and growth opportunity can reach a consensus decision or approximate an appropriate capital structure for a particular firm. Capital structure decision differs across the firms due to the presence of heterogeneity in the capital structure. This study contributes to this regard.

Empirical literature shows that multidimensional factors including firm size, earning capacity, type of assets the firm holds, future growth opportunities linked with the capital structure decision of a firm determine the capital structure of the firms. It is found that leverage is negatively associated with the size of the firm, profitability (Myers \& Majlif, 1984), and the tangible assets (Bradley, Jarrell, \& Kim, 1984). Availing the tax shield benefit is another important reason among others for favouring debt financing in capital structure decisions. Modigliani and Miller (1958) in their hypothesis argued that in the presence of corporate tax a firm with debt financing tends to have a higher value compared to the same-sized firm without debt financing. However, this is less focused on the firms enlisted in the DSE.

This paper investigates the relationship of leverage or debt financing with the nature of its asset, earning capability, size of the firm, and firm's future growth potentials. A few studies have focused on this topic using the historical data for some listed firms of the Dhaka Stock Exchange (DSE). Jahan (2014) in her empirical study tried to find the determinants of the listed Textile industry's capital structure in Bangladesh using panel data. Using the fixed-effect model it was found that profitability and tangibility are the crucial factors for determining 
the capital structure for listed Textile industries in Bangladesh. Islam (2016) also explored the determinants of the capital structure for the 63 manufacturing companies in Bangladesh using the panel data for the DSE-listed firms during the period 2008 to 2012. This study finds that the pecking order theory of capital structure is dominant in determining the capital structure for Bangladeshi manufacturing firms. It also concludes that internally generated cash flows are the most suitable source of financing for profitable firms. In another empirical investigation on 44 DSE-listed firms over eight years, it is found that the earning capability of a firm has a significant negative impact on leverage whereas the ratio of the market value and book value has a positive impact (Alom, 2013). However, it finds no relevance to consider the size of a firm as a determinant of leverage. Hossain and Ali (2012), using the fixed-effect regression approach over the 39 DSE-listed firm's data from 2003-2007, found that the size of a firm has no significant impact on capital structure though tangibility and profitability have positive impacts on leverage. On the contrary, growth opportunity has a significant negative impact on capital structure decisions. This study considers the longer period and up-to-date data (2006-2015) compared to the previous studies for identifying the determinants of leverage. Moreover, this study provides a broader view of the determinants of leverage or capital structure of the overall industry in Bangladesh, rather than any specific type of industry. Finally, we use the Feasible Generalized Least Square (FGLS) to provide more unbiased and consistent estimates compared with the previous studies.

\section{Theoretical Background}

In a world with corporate tax, agency cost, bankruptcy cost, efficient market, and information asymmetry firms are better off by availing the optimum amount of debt as it gives tax benefits to the firms to increase their values (Modigliani \& Miller, 1958). This fundamental theory of capital structure demonstrates that a firm without a corporate tax structure is independent in deciding its capital structure as the firm's value remains the same irrespective of its financing decision. In contrast, if a firm avails debt financing in the presence of corporate tax, agency cost, bankruptcy cost, efficient market, information asymmetry, it reduces the profit before tax and increases the value of the firm as the firms pay less tax in this case. Modigliani and Millar (1958) argue that a corporate firm in the tax world is better off as corporates are taxed on after interest earnings. Moreover, it can avail as much debt as possible based on the assumption of no 
transaction cost and uniform borrowing rate. They also argue that a firm becomes riskier due to an increase in the cost of capital, which might increase as the equity holders demand more return. But as a firm consistently increases its debt level it becomes vulnerable to default risk on fixed interest expense payment. So, the cost of bankruptcy becomes a headache when a firm decides to get debt financing. Therefore, there is a limit or trade-off for using excessive debt capital in the capital structure of a firm.

Many researchers have different opinions about a firm's optimal capital structure, and many have criticized Modigliani and Millar's hypothesis. For example, Jensen and Meckling (1976) argue that there is a trade-off between agency cost and optimal capital structure. Firm managers have an incentive to look after their benefit as there is no strong monitoring from the equity capital providers. Agency theory suggests in absence of proper monitoring, separation of ownership and management allows a conflict of interest between management and stockholders. Jensen (1986) in his free-cash-flow hypothesis argues using more debt can work as a solution to resolve agency problems between management and owner. As debt increases the fixed obligation of paying interest, it reduces the free cash flow of the firms. Moreover, managers will not be able to invest enough cash in junk projects as firms have less free cash flow now. This Trade-off Theory (taxbankruptcy trade-off) of capital structure deals with the cost and benefit analysis of using debt and equity in corporate financial decision making. Therefore, the Trade-off Theory suggests for each firm there should be an optimal capital structure. Firms with both below or above the optimal structure always end up with undervaluation.

Another line of theory works on the ordering of financing, which implies that a firm can finance using either from internal sources or from external sources. Internal sources include any financing generated by a firm's operation (retained earnings, free cash flow) whereas external financing includes borrowing or raising funds from external sources (debt) or its equity holders (equity). Myers and Majluf (1984) argue that equity share is the last resort of financing where firms first choose internally generated funds (retained earnings). Henceforth, it moves in packing order for financing by borrowing from external sources, followed by raising equity by issuing new shares. They argue that in a world of asymmetric information, raising funds by issuing capital has a negative signal in the market regarding the management perception about the overvaluation of its stock price in 
the market. This information asymmetry supports issuing debts instead of equity for additional financing as it signals the market about the confidence of the firm of its prospective investment returns at the same time the undervaluation of the stock in the market. It explains the inverse relationship between the earnings capacity of a firm and its use of debt. If a firm generates sufficient profit to finance its new investment opportunities, then it should first try to use it as it will give the internal users the best benefit with the least cost. If the financing need is more than the internally generated cash flows, then the firm should go for debt financing as it will have a positive effect on the firm's stock price by showing management confidence about generating sufficient return from the borrowed firm for the stockholders. Borrowing tends to have a positive impact on stock prices in the market. Then as the last choice if its financing need is not met with either internal fund or debt it can go for equity financing. But issuing equity is costlier then raising fund from issuing debt and it will have a negative signal in the market about the stock price of the firm as management tend to raise fund by issuing new stock when they perceive the stock price is overvalued.

\section{Empirical Literature}

Several factors such as profitability, firm size, nature of the asset, growth opportunity, industry classification, corporate tax structure, economic outlook, current debt level, etc. determine the capital structure decision of a firm. Many researchers over the years have assessed the relationships of these factors with the capital structure. It is found that leverage is negatively related to volatility (Bradley et al., 1984; Titman \& Wassels, 1988; Kester, 1986). Similarly, Bradley et al. (1984) found that the leverage of the firms is negatively associated with advertising, and research \& development expenditure. However, it is positively related to a non-debt tax shield (Chaplinsky \& Niehaus, 1990; Bradley et al., 1984).

In the case of measuring the influence of the growth opportunities of the firms on leverage, mixed empirical findings are evident. For example, Titman and Wassels (1988) and Chaplinsky and Niehaus (1990) find that growth opportunities negatively influence the leverage whereas Kester (1986) finds a positive association between them. Findings also contradict the case of identifying the firm size as a determinant of the capital structure. It is evidenced that firm size has both a negative impact (Chaplinsky \& Niehaus, 1990; Kester, 1986; Kim \& Sorensen, 1986; Titman \& Wassels, 1988) as well as a positive impact on 
leverage (Friend \& Hasbrouck, 1988; Marsh, 1982). Empirical evidence finds the strong positive relationship between leverage and fixed assets as fixed assets positively influence the leverage (Friend \& Hasbrouck, 1988; Gonedes, Lang, \& Chikaonda, 1988; Long \& Malitz, 1985; Marsh, 1982; Titman \& Wassels, 1988). However, studies find that profitability influences the leverage both negatively (Gonedes et al., 1988; Kester, 1986; Titman \& Wassels, 1988; Friend \& Hasbrouck, 1988; Chaplinsky \& Niehaus, 1990) and positively (Long \& Malitz, 1985). Therefore, there exist mixed findings on the direction or relationship of different explanatory variables with the outcome variable of leverage. This paper identifies the relationship of leverage with the different factors such as asset (tangibility), earnings capacity (profitability), size of the firm (size), and growth opportunity of the firm (market value to book value ratio) for the enlisted companies in the DSE.

\section{Analysis of the Expected Directions}

This section highlights the predictions concerning the expected direction of each explanatory variable considered for our analytical purpose. Though the assets of a firm are of different categories such as fixed or current, tangible, or intangible, real or fictitious, etc., two types of assets (i.e., tangible and intangible assets) are usually used for analysing leverage. Tangible assets including property, plant, and equipment, etc. have their physical existence and they are frequently traded in the market as they are valued with reasonable certainty by the outsiders. On the other hand, intangible assets like goodwill, trademark, copyright, loyalty, patent, etc. have no physical existence and they are not frequently traded in the market as well. Therefore, providing value to intangible assets face difficulties to an outsider. Also, firms use physical assets as collateral while availing debt from the bank and non-bank financial institutions. Therefore, this study expects to derive a positive relationship between leverage and tangibility using data from the enlisted companies at the DSE.

Measuring the profitability of a firm is closely associated with its earning capacity, which refers to the earnings after deducting the expenditures incurred. The more earning capacity of a firm indicates its better financial strength and thus, the better debt servicing capacity of the firm (i.e., less debt). The Pecking Order Theory clarifies that the more profitability of a firm negatively influences the amount of debt financing. Further clarification concerning this issue implies 
that more profitable firms use their internal financing source (retained earnings) to generate new projects rather than their external financing source (i.e., debt from the lenders). Consistent with the Pecking Order Theory, this paper also presumes an inverse relationship between leverage and profitability of the firms (Myers \& Majluf, 1984). However, the Trade-ff Theory hypothesizes a positive relationship between leverage and profitability. As profitable firms can easily service their debts and they are less likely to face financial distress, it is more likely that they borrow more compared with the less profitable firms.

The asset base of a firm determines the firm size, which works as a basis of taking debt from the financial institutions. For example, financial institutions rely on the size of a firm, and therefore, it is easier for the larger-sized firms to avail more credit compared with the smaller-sized firms. Moreover, a significant relationship between the profitability and size of a firm implies that the largersized firms have higher earning capacity as they depend more on their internally generated funds rather than the external debt financing. The Pecking Order Theory also argues that there persists an inverse relationship between the size of the firm and debt financing. However, this contrasts with the Trade-off Theory, which postulates a positive relationship between debt financing and firm size. It argues that a firm with more fixed tangible assets is less likely to face financial distress and it is more likely to use more debt financing.

A higher Market to Book Value (MBV) ratio indicates a firm to have higher growth potentiality, which requires maintaining additional financing by using either debt or equity financing. This makes the relationship between growth opportunity and leverage quite ambiguous. Trade-off Theory assumes a firm with higher growth opportunity is expected to borrow less as potential growth firms are highly associated with financial distress cost. Therefore, as per the Trade-off Theory, the high growth opportunity is related to low leverage. In contrast, the Pecking Order Theory presumes the inverse relationship between them as it supports first the internal financing (retained earnings), followed by debt financing (external borrowings) and equity financing, respectively. As high growth firms are expected to have the lower free cash flow, it runs short of its retained earnings. As a result, it has to look for debt financing. Therefore, the Pecking Order Theory somewhat supports the idea of a positive relationship between growth opportunity and debt financing. 


\section{Data and Methodology}

This study is based on historical financial data available from the financial statements of different companies listed on the Dhaka Stock Exchange. Some specific variables from a variety of available data are picked so that these could fulfil the interest of this study. An up-to-date period of ten years 2006-2015 has been considered to understand the capital structure phenomenon of the enlisted companies at the Dhaka Stock Exchange. Only year-end annual data has been considered for this study. All the listed companies with available data are included in the study. This study considers some variables as proxies for measuring the capital structure to understand how the enlisted companies at the Dhaka Stock Exchange decide their capital structure, which depends on other explanatory variables.

Capital structure, which is of our main concern, can be assessed in many different ways. For example, it may assume as the composition or share of debt and equity on a firm's overall assets or the number of assets financed by debt, and so on. This study takes the 'debt ratio' (total debt/ total asset) or the percentage of total assets financed by outsiders as the proxy measure for the capital structure. The outcome or the dependent variable 'capital structure' refers to the leverage of the firms, which choose their optimum leverage structure to maximize its operating profit as per the Modigliani-Miller (M\&M) theorem in a world with corporate tax.

The empirical literature on this topic has identified the four main explanatory variables such as tangibility, profitability, size of a firm, and market-to-book value ratio that influence the capital structure decision of a firm. This study has used these factors as determinants of capital structure to determine the relative strengths and directions for the firms enlisted in the DSE. This study uses the term 'tangibility', which refers to the physical existence of something belonging to the company. The tangibility of a firm indicates the proportion of its physical assets evaluated at market value. The size of tangible assets owned by a firm influences the capital structure decision as the firm can use tangible assets as collateral for long-term debt financing. This study uses 'tangibility' as one of the explanatory variables and defines tangibility as the proportion of fixed tangible assets, also known as property, plant, and equipment (PP\&E), in the overall asset of the firm (i.e., PP\&E/Total Assets).

Most of the studies use that earning capability or profitability as the surrogate for measuring the firm's operating efficiency, which shows how efficiently a firm 
utilizes or operates its assets or resources for generating profit. Moreover, the firm's operating efficiency is linked with the capital structure as it influences the capital structure decision of a firm. This study uses and defines profitability as the ratio of earnings before interest and tax (EBIT) and a firm's total asset.

The vision and mission of many firms in modern times are to grow big and the size of a firm specifies how big a firm is in terms of its asset base. Firms grow big as they continue their business for a long time or extend their business through product variation and diversification. The bigger a firm is the more renowned the firm is in the market. And as a firm become big it may need more financing to support its growth opportunity or in another way, a bigger company may get easy access to external financing with some competitive advantages. Therefore, the size of a firm influences the capital structure decision, and thus, the size of a firm is included as an explanatory variable for measuring its influence on the capital structure. The size of a firm is defined as the total assets of the firms enlisted in the DSE and expressed is in the form of logarithm.

The Market-to-Book Value ratio indicates the market outlook towards the growth opportunity of a firm. When a firm grows in its operation, it requires fresh funds from different sources to meet up its new investment requirements. Therefore, growth opportunity has some correlation with capital structure. For this reason, the Market-to-Book Value ratio is taken as an independent variable in this study. The ratio between the market capitalization and Book Value of outstanding shares defines the. Market-to-Book Value ratio. Besides, this study used year dummy variables as independent variables to control for specific year effects in the panel regression approach. Table 1 summarizes the dependent and explanatory variables used in the study.

Table 1: Summary of dependent and independent variables

\begin{tabular}{lccc}
\hline Variable ID & Type & Variable's Focus & Variable Derivation \\
\hline Leverage & Dependent & Capital Structure & Total Debt/ Total Assets \\
Tangibility & Independent & Share of Fixed Assets & PP\&E/ Total Assets \\
Profitability & Independent & Earning Capacity & EBIT/ Total Assets \\
Size & Independent & Asset Base & $\ln$ (Total Assets) \\
MktBook & Independent & Growth Outlook & Capitalization/Book Value \\
dyear & Independent & Controlling year effects & Stata command \\
\hline
\end{tabular}


A balanced panel dataset has been used for this study to identify the influential determinants of capital structure decisions using data from the different listed firms in the Dhaka Stock Exchange. At first, an Ordinary Least Square (OLS) regression model is used to observe the effect of different independent variables on leverage and show how and which of the independent variables are significantly associated with the dependent variable. These findings are not reported for simplicity. Moreover, fixed effect regression results in our case suffer from the problems of heteroscedasticity and first-order serial correlation and produce bias results for the variables of our interest. As feasible generalized least square (FGLS) can treat the problems of heteroscedasticity, first-order serial correlation and even crosssectional dependence, we analyse the findings derived from the application of FGLS.

The regression model that has been used to determine capital structure is as follows:

$$
\text { Leverage }_{i t}=\beta_{0}+\beta_{1} X_{1 i t}+\beta_{2} X_{2 i t}+\ldots+\beta_{n} X_{n i t}+\varepsilon
$$

Here,

Leverage $_{i t}=$ Total Debt to Total Asset Ratio for the $\mathbf{i}^{\text {th }}$ firm at time $\mathbf{t}$;

$\mathrm{X}_{\mathrm{n} \text { it }}=$ Independent factor $\mathbf{n}$ of the $\mathbf{i}^{\text {th }}$ firm at time $\mathbf{t}$ influencing the capital structure;

$\beta_{0}=$ Average proportion of leverage, also known as the regression intercept;

$\beta_{\mathrm{n}} \quad=$ Coefficient of the $\mathbf{n}^{\text {th }}$ explanatory variable;

$\varepsilon \quad=$ Error term of the model.

\section{Results and Discussions}

Descriptive Analysis

To find the capital structure behaviour using historical data for the listed companies at the Dhaka Stock Exchange, we first focus on the descriptive statistics of the dependent and explanatory variables. Table 2 below provides the statistical background for the data of our interest from 2006 to 2015. 
Table 2: Descriptive statistics

\begin{tabular}{lccccc}
\hline Variable & Obs. & Mean & Std. Dev. & Min & Max \\
\hline Leverage & 218 & 0.2009 & 0.2119 & 0.0000 & 0.9392 \\
Tangibility & 218 & 0.5764 & 0.2566 & 0.0052 & 0.9963 \\
Profitability & 218 & 0.1476 & 0.0961 & -0.0644 & 0.5515 \\
Size & 218 & 16.0993 & 1.1177 & 12.0407 & 18.4310 \\
MktBook & 218 & 8.6881 & 32.2590 & 0.3338 & 421.5990 \\
\hline
\end{tabular}

Findings show that the listed firms in the DSE are using around 20 percent debt financing and it comparatively quite low. The variation of the leverage ratio stands at around 21 percent, which is high, implying some firms are using very low or no debt at all and some are using quite a significant amount of debt for financing their projects. The tangibility ratio shows a unique characteristic of the companies. Most of the companies hold a very high proportion of their assets as fixed tangible assets. It is about 58 percent on average for all the companies with a variability of 26 percent. The profitability ratio shows that on average the DSE listed companies earn around 15 percent return on their assets with an acceptable variability. If we consider the maximum and minimum values for profitability ratio, it shows that some of the companies incur losses up to around 6 percent whereas some companies generate more than 55 percent earnings before income and tax. The presence of a huge variation in the variable 'size' implies significant asset base differences among the listed firms.

\section{Correlation Analysis}

Now we apply the correlation approach to explore the issue of multicollinearity among the independent variables. In addition, it is also possible to observe at a glance how the independent variables are associated with the dependent variable. Table 3 reports the correlation matrix showing the bivariate linear relationship between variables. The correlation matrix helps to identify the presence of multicollinearity. The correlation coefficients reported in Table 3 below show that there is no issue of multicollinearity persisting in the dataset.

Table 3: Correlation matrix

\begin{tabular}{lccccc}
\hline & Leverage & Tangibility & Profitability & Size & MktBook \\
\hline Leverage & 1 & & & & \\
Tangibility & 0.10 & 1 & & & \\
Profitability & $-0.40^{* * *}$ & 0.01 & 1 & & \\
Size & $0.22^{* * *}$ & $-0.22^{* * *}$ & $-0.18^{* * *}$ & 1 & \\
MktBook & 0.09 & -0.01 & $0.12^{*}$ & $-0.20^{* *}$ & 1 \\
\hline
\end{tabular}


The correlation matrix shows that the outcome variable, leverage, is positively correlated with tangibility or the level of fixed assets owned by a firm. It implies that the more fixed asset a firm owns the higher the probability of outside financing a greater proportion of those assets though the estimated correlation coefficient is not statistically significant. This positive correlation between leverage and tangibility is consistent with the empirical evidence found by Friend and Lang (1988), Gonedes, et al. (1988), Long and Malitz (1985), Marsh (1982), Titman and Wessels (1988). This relation is also consistent with the Trade-off Theory and it also shows that the greater is the fixed asset base of a listed firm in the Dhaka Stock Exchange, the easier it is for them to access in the debt market. This becomes possible due to the fact that fixed assets serve as good collateral for debt financing.

Profitability is highly negatively related with leverage and the estimated correlation coefficient seems quite strong and highly statistically significant as well. This indicates when the listed firms in the Dhaka Stock Exchange earn positive profit it does not feel interested to finance its activity through borrowing. This result is consistent with the findings of the Pecking Order Theory. Friend and Lang (1988), Gonedes et al. (1988), Kim and Sorensen (1986), Titman and Wessels (1988) also find similar results in their studies. Another important independent variable is the 'size' of a form, which is positively correlated with leverage. This indicates that the greater asset base of a company in the Dhaka Stock Exchange has the higher level of debt in its capital structure. This result is consistent with the Trade-off Theory of capital structure which says bigger firms tend to use outside financing more for their business activities. Friend and Lang (1988), Marsh (1982) also found similar kind of results in their studies.

Finally, market-to-book value is also positively related to the level of leverage for the listed companies in the Dhaka Stock Exchange. This specifies that if a company listed in DSE has a larger growth opportunity it tends to go for debt financing. This relation is consistent with the Pecking Order Theory which tells when a firm grows quickly it runs short of its internal source of financing and therefore requires external borrowings. This result for DSE listed companies is consistent with the findings of Myers and Majluf (1984).

\section{Regression Analysis}

The objective of this paper is to find out what determines the capital structure choices for the listed companies in the Dhaka Stock Exchange. To see a clear relationship between the variables of interest and leverage, this study checks 
whether fixed- or random-effects models using the Hausman test, which tells us to use the fixed-effects regression models. We have included the very commonly used variables: tangibility, profitability, size, and market-to-book value ratio to determine the capital structure or leverage. The fixed-effects model has used the year dummy variables to control for year-specific variations. As we know that fixed-effects regression on panel data are highly likely to result in a biased estimation due to the problems of heteroskcedasticity, serial correlation and cross-sectional dependence. Woolridge test for autocorrelation in panel data finds the estimate of $F(1,34)=11.326$ with Prob $>F=0.0019$. Therefore, we strongly reject the null hypothesis of no serial correlation of our case. Moreover, this study applies the modified Wald test for groupwise heteroskcedasticity in fixed effect regression model and finds the estimate of chi2 $(48)=18091.53$ with Prob $>$ chi $2=0.0000$, implying the presence of heteroskcedasticity problems. However, applying the conventional test of Variance Inflation Factor (VIF) for checking the presence of multicollinearity shows that there is no significant multicollinearity in the model. Based on the post estimation diagnoses, we can conclude that fixed effect estimates suffer from autocorrelation and heteroskcedasticity. As feasible generalized least square (FGLS) can treat the problems of heteroskcedasticity, first-order serial correlation and even crosssectional dependence, we analyses the findings derived from the application of FGLS. Table 4 summarizes the regression results of FE, RE and FGLS models. However, we are interested in explaining the estimates using the FGLS as it can capture the problems addressed above.

Table 4: Estimated results from OLS, Fixed-Effects (FE), and Random-Effects (RE) Models

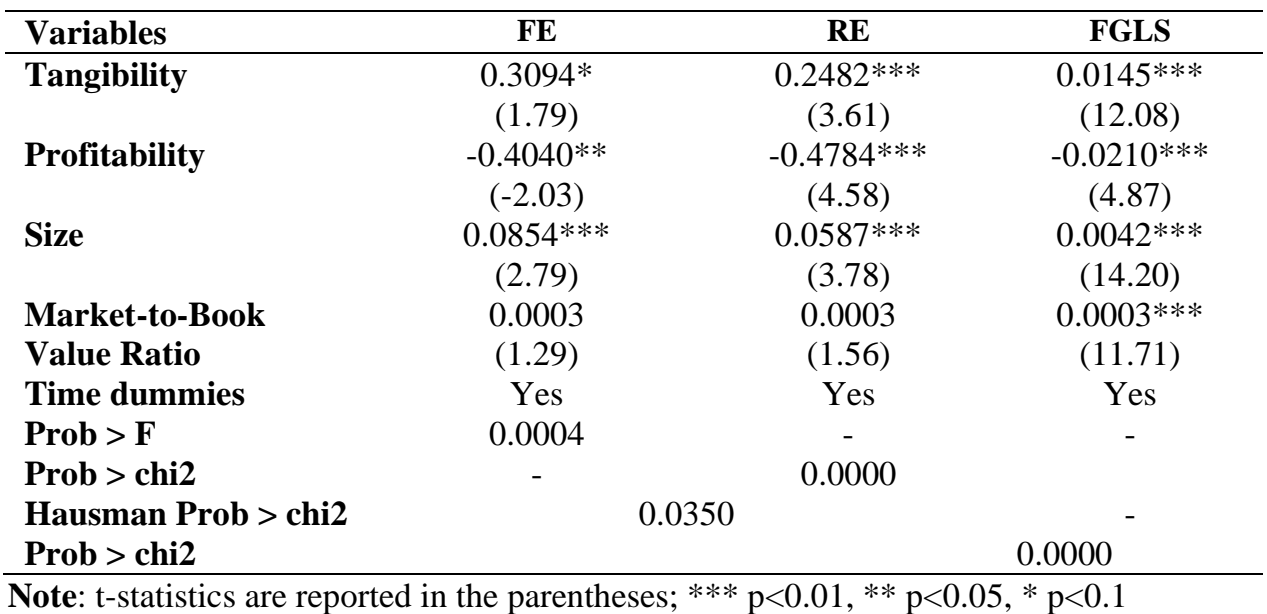


Table 4 shows that estimates from FE, RE and FGLS models are consistent in terms of signs. All the models show that tangibility, size, and market-to-book value ratio positively influence the leverage of the listed firms in the Dhaka Stock Exchange. This study explains the estimates obtained using the FGLS as it helps to reduce the bias.

This study using the FGLS shows that tangibility positively impacts the leverage of the companies listed in the DSE, which follows the Trade-off Theory of capital structure. It implies that a company listed in the DSE with more tangible fixed assets has more leverage. However, a firm with more profitability in Bangladesh tends to borrow less. This means that a firm or company significantly reduces its leverage as the profitability increases. The FGLS regression coefficient of profitability is found to be significant at a 1 percent level and consistent with the Pecking Order Theory. Since more profitable firms have more internal funding to operate its existing and new projects, they are less interested in borrowing from an outside source. It moves through the pecking order of financing as indicated by the negative coefficients.

The variable, size, is very highly significant at 1 percent level for all models. The coefficient using the FGLS for the variable 'size' is around 0.004, which states that if the size of the firms in the DSE increases, leverage also increases. As big firms have better access to the debt market, they can borrow more from an outside source. Finally, the market-to-book value ratio is positive for all models. But it is highly significant only for the FGLS at 1 percent level. This indicates the growth opportunity of a company in the Dhaka Stock Exchange does play role on capital structure decision making.

\section{Conclusion}

The economic development of a country hugely depends on its capital formation. The stock market or capital market is a place where firms are listed to raise equity capital and goodwill. Listing in the stock market requires fulfilment of certain conditions and regulatory requirements which gives the listed companies better reliability than other non-listed companies. It also gives listed companies to get easy access to the debt market to further fundraising. This study aims to find the capital structure determinants for the listed firms in the Dhaka Stock Exchange. Over the recent ten years of study, this study finds the consistent estimates using the different approaches. Using FGLS this study confirms that tangibility, size of the firms and market-to-book value ratio positively impact the leverage of the companies enlisted 
in the DSE. Only profitability negatively impacts the leverage. There exists a positive relationship between leverage and tangibility which is consistent with the Trade-off Theory of capital structure. A negative relationship is observed between leverage ratio and profitability and it is found consistent with the Pecking Order Theory of capital structure. The leverage ratio is positively related to firm size or asset base and it supports the Trade-off Theory of capital structure. Finally, the firm's growth opportunity is financed by enhancing the leverage ratio as indicated by significant positive relationship between leverage and market-to-book value ratio. Finding is consistent with the Pecking Order Theory.

\section{References}

Alom, K. (2013). Capital structure choice of Bangladeshi firms: An empirical investigation. Asian Journal of Finance \& Accounting, 5(1), 320.

Bradley, M., Jarrell, G. A., \& Kim, E. H. (1984). On the existence of an optimal capital structure: Theory and evidence. The journal of Finance, 39(3), 857-878.

Chaplinsky, S., \& Niehaus, G. (1990). The determinants of inside ownership and leverage. Ann Arbor, University of Michigan, Working Paper.

Friend, I., \& Hasbrouck, J. (1988). Determinants of Capital Structure. In Andy Chen (ed.) Research in Finance.

Friend, I., \& Lang, L. H. (1988). An empirical test of the impact of managerial self-interest on corporate capital structure. the Journal of Finance, 43(2), 271-281.

Gonedes, N. J., Lang, L., \& Chikaonda, M. (1988). Empirical Re-suits on Managerial Incentives and Capital Structure. The Wharton School, University of Pennsylvania, Working Paper.

Hossain, F., \& Ali, A. (2012). Impact of firm specific factors on capital structure decision: an empirical study of Bangladeshi Companies. International Journal of Business Research and Management, 3(4), 163-182.

Islam, R. (2016). Determinants of capital structure choices for listed manufacturing companies in Bangladesh. Research Journal of Finance and Accounting ISSN, 2222-1697.

Jahan, N. (2014). Determinants of capital structure of listed textile enterprises in Bangladesh. Research Journal of Finance and Accounting, 5(20), 11-20.

Jensen, M. C. (1986). Agency costs of free cash flow, corporate finance, and takeovers. The American economic review, 76(2), 323-329.

Jensen, M. C., \& Meckling, W. H. (1976). Theory of the firm: Managerial behavior, agency costs and ownership structure. Journal of financial economics, 3(4), 305-360.

Long, M., \& Malitz, I. (1985). The investment-financing nexus: Some empirical evidence. Midland Corporate Finance Journal, 3(3), 53-59.

Modigliani, F., \& Miller, M. H. (1958). The cost of capital, corporation finance and the theory of investment. The American economic review, 48(3), 261-297.

Myers, S. C., \& Majluf, N. S. (1984). Corporate financing and investment decisions when firms have information that investors do not have (No. w1396). National Bureau of Economic Research.

Titman, S., \& Wessels, R. (1988). The determinants of capital structure choice. The Journal of finance, 43(1), 1-19. 